\title{
IMPLEMENTATION OF LEGAL AID BY THE LOCAL GOVERNMENT (CASE STUDY OF THE LOCAL GOVERNMENT OF JEMBER REGENCY)
}

\author{
Tiara Putri Syahara \\ Local Government and Justice Studies Center, Jember, Indonesia \\ *Email: tiaraputri@gmail.com
}

Basically, the right to obtain defense from an advocate or public defender (access to legal counsel) is a human right of all people and is one of the elements to obtain justice for everyone. However, in reality, local governments generally only provide legal assistance on a non-litigation basis where its implementation does not burden the regional budget at all. Based on this, the researchers made two problem formulations, namely 1). How to protect the community through the provision of legal aid and 2). How is the implementation of the provision of legal aid by the local government? The author uses a normative juridical research approach. From the results of the study, it was found that the provision of legal aid is not only regulated in the Constitution but is also regulated in the regulations below it up to the Regional Regulation level. Local

The Indonesian Journal of International Clinical Legal Education DOI: https://doi.org/10.15294/ijicle.v3i4.48282

Submitted: Dec 12, 2020 Revised: March 13, 2021 Accepted: August 10, 2021 Available online at https://journal.unnes.ac.id/sju/index.php/iccle (C) 2021 Authors. This work is licensed under a Creative Commons AttributionShareAlike 4.0 International License (CC BY-SA 4.0). All writings published in this journal are personal views of the authors and do not represent the views of this journal and the author's affiliated institutions. 
Tiara Putri Syahara

governments can allocate funds for the implementation of legal aid in the $A P B D$.

Keywords: Underprivileged Community; Legal Aid; Poor People

\section{INTRODUCTION}

Basically, Indonesia is a country that adheres to the rule of law, which is stated in Article 1 paragraph (3) of the 1945 Constitution of the Republic of Indonesia. In addition, to strengthen Article 1 paragraph (3) this is also constitutionally regulated in Article 27 paragraph (1) of the 1945 Constitution of the Republic of Indonesia which states, "Every citizen has the same position under the law and the government with no exceptions", and is reaffirmed in Article $28 \mathrm{D}$ of the Law. The 1945 Constitution of the Republic of Indonesia which states, "Everyone has the right to recognition, guarantee, protection, and legal certainty that is fair and equal treatment before the law."

The regulation illustrates that the government does not give specialization to a certain person or group of people or discriminate against a certain person or other group of people. Therefore, all people without exception have the same rights in obtaining justice and equality before the law. This principle also guarantees respect for human rights, including the right to obtain justice (access to justice) and equality before the law (equality before the law). ${ }^{1}$

1 In the other context, the Legal Aid also provide a social justice protection for the people. Social justice is the relation of balance between individuals and society measured by comparing distribution of wealth differences, from personal liberties to fair privilege opportunities. In Western as well as in older Asian cultures the concept of social justice has often referred to the process of ensuring that individuals fulfill their societal roles and receive what was their due from society. In the current global grassroots movements for social justice, the emphasis has been on the breaking of barriers for social mobility, the creation of safety nets and economic justice. Social justice assigns rights and duties in the institutions of society, which enables people to receive the basic benefits and burdens of cooperation. The relevant institutions often include taxation, social insurance, public health, public school, public services, labor law and regulation of markets, to ensure fair distribution of wealth, and equal opportunity. Please also see Laurens Bakker, and Jaap Timmer. "Justice in Indonesia: The social life of a momentous concept." The Asia Pacific Journal of Anthropology Vol. 15 No.4, 2014, pp. 293-301; Kukuh Santiadi, "Expanding Access to Justice through E-Court in Indonesia." Prophetic Law Review Vol. 1 No. 1, 2019, pp. 75-89; Roanne Van Voorst, "The right to aid: perceptions and practices of justice in a flood-hazard context in Jakarta, Indonesia." The Asia Pacific Journal of Anthropology Vol. 15 No.4, 2014, pp. 339356, Widya Naseva Tuslian, "Assessing Development of Access to Justice in 
In line with this understanding, the 1945 Constitution of the Republic of Indonesia also provides constitutional guarantees for the poor and with special needs who are the most vulnerable to discrimination and injustice, namely Article 34 states that "the poor and neglected children are cared for by the state". With this arrangement, the protection of the poor and neglected children is also the responsibility of the state. In addition, the form of protection of human rights, including by providing guarantees and protection so that everyone has the same position before the law with no exceptions. The existence of these guarantees and protections provides an indication of the importance of providing legal aid in order to ensure that everyone's rights can be protected from discriminatory legal actions so that what is the goal of the state to create equality before the law, can be carried out because of the functioning of the legal aid. ${ }^{2}$

Further regulation regarding the right of everyone to obtain legal assistance has also been regulated in the Law of the Republic of Indonesia Number 39 of 1999 concerning Human Rights concerning basic rights that must be respected. As we know, human rights are a set of rights that are inherent in the nature and existence of humans as creatures of God Almighty and are His gift that must be respected, upheld and protected by the state, law, government, and everyone for the sake of honor and protection. human dignity and self-worth. Based on this, the state is obliged to guarantee the basic rights of everyone.

Basically, the right to obtain a defense from an advocate or public defender (access to legal counsel) is a human right of all people and is one of the elements to obtain justice for everyone. Aristotle stated that justice must be distributed by the state to all its citizens and the law has the duty to maintain it so that justice reaches everyone. When two disputing persons appear before a judge, they must be treated equally (audi et alteram partem). If people can afford to be defended by advocates, then even the poor must be able to provide public defenders on a pro bono publico basis. This defense is carried out without regard to the background of the individual concerned, such as religion, ancestry, race, ethnicity, political beliefs, socio-economic strata, skin color, and gender.

The enactment of Law Number 16 of 2011 concerning Legal Aid provides an affirmation of the rights of citizens, especially the poor, to obtain legal assistance. However, in practice, access to justice and equality before the law has not been evenly distributed for all groups, especially for the poor or underprivileged. However, the right to free

Indonesia Through Capability Approach." 3rd International Conference on Law and Governance (ICLAVE 2019). Atlantis Press, 2020.

2 Bagir Manan, Perkembangan Pemikiran dan Pengaturan Hak Asasi Manusia di Indonesia, Yayasan Hak Asasi Manusia, Demokrasi dan Supremasi Hukum, Bandung: Alumni, 2001, pp. 59-60. 
legal aid for people who can't afford it in practice in the field, it is suspected that there are still irregularities committed by several law enforcement officers. This has resulted in the provision of free legal aid so far not being able to meet the needs of most justice seekers from the poor. They are forced to deal with the law without the assistance of an advocate which results in continued injustice and discrimination in the law. ${ }^{3}$

As comparison data in 2012, the Center for Research and Development on Civil and Political Rights has conducted a Research on the Role of Local Governments in Fulfilling the Right to Justice (a study on access to legal aid for the poor) with the result that there are three patterns in the provision of legal aid, namely the provision of nonlitigation legal aid, litigation and a combination of non-litigation with litigation, but local governments generally only provide non-litigation legal assistance where its implementation does not burden the regional budget at all. Then there are supporting and inhibiting factors in the fulfillment of legal aid rights for the poor. One of the inhibiting factors is the ignorance of the poor in getting the right to justice in the form of providing legal assistance for litigants in court. ${ }^{4}$

Therefore, based on the phenomena that have been discussed previously, it is worth asking two things, namely, first, how is the implementation of the provision of free legal aid (pro bono publico) by local governments for the poor. By providing a glimpse through the description of the provision of legal aid by the local government in Jember Regency. From the description above, the researcher made two problem formulations, namely 1 ). How to protect the community through the provision of legal aid and 2). How is the implementation of the provision of legal aid by the local government.

Method The approach used in this study is a normative juridical method. Considering that the problems being researched and studied adhere to the juridical aspect, namely based on norms, regulations, legislation, legal theories, the opinions of legal experts, especially in this case are the legal rules relating to aid. law. In normative legal research, law is conceptualized as a rule or norm which is the basis for human behavior that is considered appropriate. ${ }^{5}$ This research is categorized as normative research because it examines library materials on secondary data sourced from library materials. Meanwhile, judging from its nature,

3 Dina Susiani, "Bantuan Hukum "Pro Bono Publico" Dalam Pemenuhan Hak Memperoleh Keadilan dan Persamaan di Muka Hukum di Provinsi Jawa Timur", Jurnal Panorama Hukum Vol. 5 No. 2, 2020, pp 207-208.

4 Frans Hendra Winata, Probono Publico, Hak Konstitusional Fakir Miskin Untuk Memeperoleh Bantuan Hukum, Jakarta: PT. Gramedia Pustaka Utama, 2009, pp. 1213.

5 Amiruddin \& Zainal Asikin, Pengantar Metode Penelitian Hukum, Jakarta: PT.Raja Garafindo Persada, 2006, pp. 118-120. 
this research is a descriptive-analytical research that describes the overall object under study systematically by analyzing the data obtained.

\section{COMMUNITY PROTECTION THROUGH PROVIDING LEGAL AID}

The struggle of the Indonesian people to have a national criminal procedural law, which is in accordance with human rights and especially has paid attention to the rights of suspects and defendants has been realized, this began on December 31, 1981, when the Government of Indonesia passed Law Number 8 of 1981. 1981, which became known as the Criminal Procedure Code (KUHAP).

The ratification of Law Number 8 of 1981 concerning the Criminal Procedure Code is expected to be able to deal with various problems that exist in the legal field, especially criminal law. The Criminal Procedure Code is one of the greatest works of the Indonesian nation in the field of law, which provides enormous protection for Human Rights, by regulating in detail the rights that are owned and can be obtained for suspects and defendants during the case examination process. The granting of rights to suspects and defendants is also followed by setting certain obligations to law enforcement officers, so that the rights of suspects and defendants can be realized in court practice in Indonesia.

The process of examining a case according to the Criminal Procedure Code has the aim of creating a due process of law (fair legal process) in the examination of criminal cases. This is very important to prove in practice before the court, because the protection of human rights in the criminal legal process will not mean anything if the rights that have been formulated in the Criminal Procedure Code cannot be implemented in practice. Discrimination in treatment is allowed, because the state guarantees individual rights, the only right that can be lost from a person with the status of a "suspect" perpetrator of a criminal act is the right to freedom of movement, because the law authorizes law enforcement officers to make arrests. and detention or deprivation of liberty against a suspect or defendant if there is sufficient preliminary evidence. ${ }^{6}$

Some of the rights of suspects or defendants regulated by the Criminal Procedure Code, there are very important rights, which at least must exist in a modern procedural law, including the right to obtain legal assistance. Legal Aid has an important position in every criminal justice system, including Indonesia. In general, it can be said that legal aid has goals that are directed at various social categories in society. The concept of legal aid is related to the rights of citizens to exercise these rights,

6 Mardjono Reksodiputro, Hak Asasi Manusia Dalam Sistem Peradilan Pidana, Jakarta: Pusat Pelayanan Keadilan dan Pengabdian Hukum, 1994, pp. 10-11. 
therefore Legal Aid is carried out by legal experts and experienced people in order to carry out their profession. Legal aid is run by legal aid providers who are oriented to noble values, namely the humanitarian aspect to fight for human rights to live in prosperity and justice.

The provision of legal aid can be given to everyone regardless of one's social status. This is as one of the principles in the rule of law (rechtsstaat) where the state recognizes and respects the human rights of every citizen. State recognition of individual rights is contained in one of the principles, namely equality before the law for all people. ${ }^{7}$

Based on Frans Hendra Winarta's opinion, legal aid is one of the legal services specifically provided to the poor who need a free defense, both outside and inside the court, in criminal, civil and state administration, from someone who understands the ins and outs of the law. legal defense, legal principles and rules, and human rights. Another definition was put forward by legal expert Adnan Buyung Nasution, which means that legal aid is specifically legal aid for groups of people who have low incomes or in popular language the poor, the measure of poverty to date is still a problem that is not easy to solve, not only for developing countries and even developed countries are still a problem. ${ }^{8}$

The Criminal Procedure Code (KUHAP) has appointed and placed the suspect or defendant in a position of dignity, as a creature of God who has complete human dignity. The suspect or defendant has been placed in the Criminal Procedure Code in the position of his entity and dignity as a human being, which must be treated in accordance with noble human values. The law must be enforced, but in carrying out law enforcement against a suspect or defendant, the main human rights inherent in him must not be stripped. ${ }^{9}$

Guarantees to obtain legal assistance have been regulated in Law no. 39 concerning Human Rights in Articles 17, 18, 19, and 34. Indonesia has ratified the International Covenant on Civil and Political Rights, which in Article 16 and Article 26 of the Convention guarantees equality before the law (equality before the law). Everyone has the right to protection from the law and discrimination on the basis of race, color, sex, language, religion, different political views, national or national origin, wealth, birth or other status must be avoided. ${ }^{10}$

The right to obtain legal assistance is a basic or human right for someone who is in legal trouble. Because obtaining legal assistance is one form of access to justice for those who are or are dealing with legal

7 Adnan Buyung Nasution, Bantuan Hukum di Indonesia, Jakarta: LP3ES, 2007, pp. $1-4$.

8 O.C. Kaligis, Perlindungan Hukum Atas Hak Asasi Tersangka, Terdakwa dan Terpidana, Bandung: PT Alumni, 2006, p. 237.

9 M. Yahya Harahap, Pembahasan Permasalahan dan Penerapan KUHAP Penyidikan dan Penuntutan, Jakarta: Sinar Grafika,2009, pp. 1-2.

10 A Patra M. Zen \& Daniel Hutagalung, (2006), Panduan Bantuan Hukum Di Indonesia, Jakarta: YLBHI dan PSHK, 2006, p. 47. 
problems. Obtaining legal aid is also a manifestation of equality before the law. The principle of equality before the law has been contained in Article 28D paragraph (1) of the 1945 Constitution, namely that everyone has the right to recognition, guarantees, protection and fair legal certainty and equal treatment before the law. This is the consequence that the State of Indonesia is a state of law (article 1 paragraph (3) of the 1945 Constitution as a result of the third amendment). There are three principles of the rule of law (rechstaat), namely the rule of law (supremacy of law), ${ }^{11}$ equality before the law (equality before the law), and law enforcement in ways that do not conflict with the law (due process of law). General provisions for obtaining legal assistance are contained in Law Number 4 of 2004 concerning Judicial Power.

Article 37 of Law no. 4 of 2004 states: "Everyone involved in a case has the right to obtain legal assistance." Article 38 of Law no. 4 of 2004 confirms: "In a criminal case, a suspect has the right to contact and ask for help from an advocate."

The process of examining a case according to the Criminal Procedure Code has the aim of creating a due process of law (fair legal process) in the examination of criminal cases. This is very important to prove in practice before the court, because the protection of human rights in the criminal law process will mean nothing if the rights that have been formulated in the Criminal Procedure Code cannot be implemented in practice. Human rights protection for suspects or defendants, discrimination in treatment is not allowed, because the state guarantees individual rights, the only right that can be lost from a person with the status of a "suspect" perpetrator of a criminal act is the right to freedom of movement, because the law provides authority to law enforcement officers to make arrests and detentions or deprivation of liberty against a suspect or defendant if there is sufficient preliminary evidence. ${ }^{12}$

Legal Aid has four concepts in its implementation. First, the concept of traditional legal aid, is that legal services are provided to the poor individually, the nature of legal aid is passive and the approach is very formal-legal. Second, the Concept of Constitutional Legal Aid, is legal aid for the poor which is carried out within the framework of broader efforts and goals such as: awareness of the rights of the poor as legal subjects, enforcement and development of human rights values as the main pillar for upholding the rule of law. ${ }^{13}$ Third, the concept of Structural Legal Aid, is an activity that aims to create conditions for the realization of a law that is able to change the unequal structure towards a

11 Asfinawati \& Mas Achmad Santosa, Bantuan Hukum Akses Masyarakat Marjinal Terhadap Keadilan Tinjauan Sejarah, Konsep, Kebijakan, Penerapan, dan Perbandingan di Berbagai Negera, Jakarta: LBH Jakarta, 2007, pp. 97-98.

12 Mardjono Reksodiputro, Hak Asasi Manusia Dalam Sistem Peradilan Pidana, Jakarta: Pusat Pelayanan Keadilan dan Pengabdian Hukum, 1994, pp. 10-11.

13 YLBHI, Panduan Bantuan Hukum di Indonesia, Jakarta: Yayasan Obor Indonesia, 2014, p. 462. 
more just structural one, where legal regulations and their implementation can guarantee equality in both the legal and political fields. The concept of structural legal aid is closely related to structural poverty. ${ }^{14}$ Fourth, responsive legal aid is provided to the poor free of charge and covers all areas of law and human rights and does not differentiate between individual and collective defense cases. ${ }^{15}$ The services provided in responsive legal assistance are in the form of legal counseling on human rights and the legal process for the right to be defended by legal aid organizations and or advocates, defense in overcoming concrete legal problems, quality defense in courts in order to produce a more firm and clear jurisprudence. and true, legal reform through court decisions that favor the truth and the formation of laws that are in accordance with the value system and culture that exists in society to make this concept successful, legal aid must become a national movement supported by the state and society.

The concept of legal aid that can help realize access to law and justice for the poor is the concept of responsive and structural legal aid. If the concept of providing legal aid is combined with the concept of access to law and justice, it is not impossible for the poor to access the law and get justice.

\section{IMPLEMENTATION OF LEGAL AID BY LOCAL GOVERNMENT}

As the implementation of a state of law, Indonesia places the law at the highest level which in its implementation must respect human rights. The existence of an independent judiciary and all government actions based on law. ${ }^{16}$ In this regard, the protection of human rights must be contained in the 1945 Constitution of the Republic of Indonesia (UUD 1945) as the Indonesian constitution. There are several articles, including Article 27 paragraph (1), Article 28D paragraph (1) and Article 34 paragraph (1) regulating the equality of position for every citizen, including the poor and abandoned children who are cared for by the state and also get recognition, guarantees, protection, and fair legal certainty and equal treatment before the law.

The main purpose of equality before the law is to uphold justice where equality of position means that the law does not discriminate against anyone who asks for justice. It is hoped that with this principle there will be no discrimination in the rule of law in Indonesia where there

14 Suradji, Etika dan Penegakan Kode Etik Profesi Hukum (Advokat), Jakarta: Badan Pembinaan Hukum Nasional Departemen Hukum dan HAM RI, 2008, p. 77.

15 Frans Hendra Winata, Loc. Cit.

16 YLBHI, Op. Cit, p. 146. 
is a difference between the ruler and his people. ${ }^{17}$ The principle of equality before the law is a guarantee to achieve legal justice, without the absence of parties who can be separated from the law when involved in the law enforcement process. The principle of equality before the law is a principle where there is equality in law for every individual without any exceptions. The principle of equality before the law can be used as a standard to confirm marginal groups or minority groups.

Legal aid is one of the rights for an incapacitated defendant which has been regulated in detail in the legislation, this does not mean that the defendant can easily obtain legal assistance from an advocate in enforcing the idea of legal aid into a reality, but there are There are also several inhibiting factors that will influence it.

According to Soerjono Soekanto, the factors that hinder law enforcement, especially in terms of legal aid are as follows: ${ }^{18}$

a. the legal factor itself, namely in the form of law;

b. law enforcement factors, namely the parties that form and apply the law;

c. factors of facilities or facilities that support law enforcement;

d. community factors, namely the environment in which the law applies or is applied; and

e. cultural factors, namely as a result of work, creativity and taste based on human initiative in social life.

Often what happens in the field, some of these factors are interrelated with each other which has an impact on the delay in the implementation of legal aid for the community by the local government.

Legal aid organizations that have been appointed by the state to provide legal assistance to the community are still experiencing obstacles in their journey, starting from the issuance of a Certificate of Disability (SKTM) to the financing factor. In Article 5 paragraph (1) of Law Number 16 of 2011 concerning Legal Aid it is explained that; "Recipients of Legal Aid as referred to in Article 4 paragraph (1) include every person or group of poor people who cannot fulfill their basic rights properly and independently."

According to Subhi Mahssani, equality before the law is interpreted as "equality legally and by law is the equality of all humans before the law, without any differences between them, either because of differences in ethnicity, skin color, religion, nation, descent, class and wealth". Furthermore, he also said that legal equality includes two aspects, namely the aspect of equality in obtaining legal protection and the aspect of equality in rights, then it is also said that equality which is a human right

17 Yesmil Anwar dan Adang, Sistem Peradilan Pidana (Konsep, Komponen, dan Pelaksanaannya dalam Penegakan Hukum di Indonesia), Bandung: Widya Padjajaran, 2009, pp. 113-115.

18 Soerjono Soekanto, Faktor-Faktor Yang Mempengaruhi Penegakan Hukum, Jakarta: PT Raja Grafindo Persada, 2008, pp. 3-4. 
is equality before the law and legislation where equality includes equal protection of their rights. ${ }^{19}$

The provision of legal aid for the poor is a manifestation of the government's efforts to regulate human rights in the legal field to equalize before the court. The enactment of Law Number 16 of 2011 concerning Legal Aid (Law on Legal Aid) has demonstrated the government's commitment to providing equal justice before the law. Article 19 of the Legal Aid Law also provides space for local governments to participate in providing free legal aid for the poor and budgeting it in the Regional Revenue and Expenditure Budget (APBD) which is regulated by regional regulations (perda). However, until the end of 2017 there were only 22 regional regulations on legal aid for the poor at the provincial and district/city levels. In terms of quantity, the fulfillment of legal aid is still inadequate to reach the poor in all regions, considering that the Regional Government itself has not given special attention to the legal umbrella for the fulfillment of legal aid in the regions in the form of local regulations. In 2016 the Tifa Foundation together with the National Legal Development Agency (BPHN), the National Development Planning Agency (BAPPENAS), and the Indonesian Legal Aid Institute (YLBHI) held a national consultation on the Legal Aid Perda which resulted in the decision that the local government's initiative was weak in enacting the Legal Aid Perda. . The implementation of this activity is due to doubts in the distribution of government affairs related to central government affairs in the field of justice. This is different from the Jember Regency Government which has ratified Regional Regulation Number 6 of 2016 concerning Legal Aid for the Poor (Perda on Legal Aid for the Poor). The problem is how to regulate the authority to administer legal aid in the regions and how to fulfill legal aid in Jember Regency after the ratification of the regional regulation.

Legal aid in question can be translated from two terms, namely "Legal Aid" and "Legal Assistance". The term Legal Aid is usually used to mean legal aid in a narrow sense in the form of providing legal services to someone in a case for free, especially for those who cannot afford it. Legal Assistance is used to show the meaning of legal aid to those who cannot afford it as well as the provision of legal assistance by advocates who use honoraria ${ }^{20}$. Legal aid in a broad sense can be interpreted as an effort to help disadvantaged groups in the legal field. According to Buyung Nasution, this effort has three interrelated aspects, namely aspects of the formulation of legal rules, aspects of supervision of

19 Mien Rukmini, Perlindungan HAM Melalui Asas Praduga Tidak Bersalah dan Asas Persamaan Kedudukan Dalam Hukum Pada Sistem Peradilan Pidana Indonesia, Bandung: Alumni, 2007, pp. 29-30

20 Abdurrahman, Aspek-Aspek Bantuan Hukum di Indonesia, Jakarta: Penerbit Cendana Press, 1983, pp. 17-18. 
mechanisms to ensure that these rules are adhered to, and aspects of public education so that the rules are adhered to. ${ }^{21}$

Clinical education is actually not only limited to criminal and civil departments to finally appear before the court, but also to other majors such as the Department of Constitutional Law, Government Administration Law, International Law and others. It is even possible to provide legal assistance outside the court, for example regarding housing at the Housing Affairs Office (KUP), assistance at Immigration or the Ministry of Justice, legal assistance to someone who concerns international affairs at the Ministry of Foreign Affairs and even providing guidance and counseling in the field of law including targeting legal aid and so on. Meanwhile, in a narrow sense the Attorney General of the Republic of Indonesia states that legal aid is a defense obtained by a defendant from a legal advisor when his case is examined in a preliminary examination or in the process of examining his case before the court. by the legal aid provider free of charge to the legal aid recipient.

With the existence of this Law on Legal Aid, it shows that the government has committed that the government seeks legal protection for the poor in order to uphold equality before the law (equality before the law). This provision on legal aid aims to guarantee and fulfill the rights of legal aid recipients (the poor) to get access to justice, to realize the constitutional rights of citizens, to guarantee certainty that the implementation of legal aid is carried out thoroughly in Indonesia, and to realize an effective, efficient and accessible judiciary. accounted for.

The implementation of legal aid based on Article 19 of the Legal Aid Law, provides space for local governments to participate in realizing the goal of legal aid for the poor as regulated in Article 3 of the Legal Aid Law. There are several statements in Article 19 of the Legal Aid Law, including that the regions can allocate a budget for the implementation of legal aid in the APBD, further provisions regarding the implementation of legal aid as referred to in paragraph (1) are regulated by a Regional Regulation.

The implementation of providing legal aid services for the poor contained in the Law on Legal Aid is not carried out directly by the government, but by the Legal Aid Institute $(\mathrm{LBH})$ which is a community organization (Ormas). The legal aid provider in the Legal Aid Law is the government, namely the Ministry of Law and Human Rights (Kemenkumham) which is technically carried out by the National Legal Development Agency (BPHN) as the central government. The role of the Ministry of Law and Human Rights in this legal aid program broadly covers 3 (three) aspects, namely making technical regulations for legal aid, managing the distribution of legal aid funds, and monitoring and evaluating the implementation of legal aid.

21 Bambang Sunggono \& Aries Harianto, Bantuan Hukum dan Hak Asasi Manusia, Bandung: Mandar Maju, 2001, pp. 23-24. 
The Implementing Regulation of the Legal Aid Law is Government Regulation Number 42 of 2013 concerning Terms and Procedures for Providing Legal Aid and Distribution of Legal Aid Funds. According to this Government Regulation, the legal aid budget is provided for litigation and non-litigation, the amount of the legal aid budget is determined by the minister in accordance with the Decree of the Ministry of Law and Human Rights Number M.HH-01.HN.03.03 of 2015 concerning the Amount of Litigation and Non-Litigation Legal Aid Fees. Based on the decision, the cost of litigation legal aid activities for legal aid providers in a criminal, civil and state administrative case, until the case has binding legal force. In addition, legal assistance is also provided for non-litigation cases including legal counseling, legal consultation, case investigation, both electronically and non-electronically, legal research, mediation, negotiation, community empowerment, out-of-court assistance and/or legal document drafting.

Based on the decision, the maximum cost of litigation for criminal and civil cases and state administration is Rp. 5,000,000, while for nonlitigation activities such as legal counseling, legal consultation, mediation and negotiation the costs vary from Rp. 140,000 to Rp. $3,740,000 .^{22}$ The distribution of legal aid funds in litigation can be submitted after the completion of the provision of legal aid by the legal aid provider to the legal aid recipient at each stage of the proceedings in court. Then the legal aid provider can submit a report accompanied by supporting evidence whose calculations are according to a certain percentage of the rate per case. Based on the standard cost of implementing legal aid in litigation by not eliminating the obligation to legal aid providers to continue to provide legal assistance until the case handled by the legal aid provider is completed or has permanent legal force. Meanwhile, the distribution of funds for non-litigation cases can be carried out after the legal aid provider has completed at least one legal aid activity in the non-litigation activity package. Then the legal aid provider submits a report that non-litigation legal aid has been held accompanied by supporting evidence for the implementation of the legal aid activity. The distribution of legal aid funds on a non-litigation basis is calculated at the rate per activity based on the standard cost of implementing legal aid on a non-litigation basis. ${ }^{23}$

The provision of legal aid in litigation can be carried out by an advocate with the status of a legal aid provider and/or an advocate

22 Soerjono Soekanto, Bantuan Hukum suatu Tinjauan Sosio Yuridis, Jakarta: Ghalia Indonesia, 1983, pp. 22-23.

23 Decree of the Minister of Law and Human Rights No. M.HH-01.HN.03.03 of 2015 concerning the Amount of Litigation and Non-litigation Legal Aid Fees (Keputusan Menteri Hukum dan Hak Asasi Manusia No. M.HH-01.HN.03.03 Tahun 2015 tentang Besaran Biaya Bantuan Hukum Litigasi dan Nonlitigasi). See also Badan Pembinaan Hukum Nasional, Implementasi Undang-Undang Nomor 16 Tahun 2011 tentang Bantuan Hukum, Jakarta: BPHN,2016, pp. 8-9. 
recruited by a legal aid provider. If the number of advocates gathered in LBH/Ormas is not sufficient with the large number of legal aid recipients. Thus, legal aid providers can recruit paralegals, lecturers, and law faculty students by attaching written evidence of assistance from advocates. Especially for law faculty students must have passed courses in procedural law and paralegal training.

The provision of non-litigation legal aid can be carried out by advocates, paralegals, lecturers, and law faculty students within the scope of legal aid providers who have passed verification and accreditation. The provision of non-litigation legal assistance includes legal counseling, legal consultation, case investigation, both electronically and nonelectronically, legal research, mediation, negotiation, community empowerment, out-of-court assistance, and/or drafting legal documents.

From several forms of legal aid that have been implemented, the fulfillment of legal aid for the poor in Jember Regency has so far not been maximized because it has not been felt by all levels of society, especially the poor in remote villages. Law enforcers seem to be less interested in serving cases involving the poor. Legal aid providers tend not to provide clear information in disbursement services to $\mathrm{OBH}$ who submit requests for disbursement of funds, so that disbursement of funds is often late. When viewed from law enforcement and legal aid providers, it still shows that the access of the poor to free or free legal aid in Jember Regency has not yet achieved equality before the law. ${ }^{24}$

When viewed from the recipients of legal aid, the socialization of legal aid provisions to the poor is less effective because there are still many poor people who do not know their rights in obtaining free legal aid. Likewise, the prerequisite procedures for applying for legal aid are difficult for the poor because the majority of them do not really care about the formalities of residence, the most important thing is that they work and earn money to survive. The culture of the people who tend to surrender and think that they will spend a lot of money if they use the services of a legal aid provider is also a separate obstacle in fulfilling legal aid, because with this culture people are reluctant to apply for legal aid.

The presence of the Law on Legal Aid has resulted in the imposition of an obligation on the Government to allocate funds for the implementation of legal aid in the APBN. Funding for the implementation of legal aid is allocated to the budget of the ministry that carries out government affairs in the field of law and human rights, in this case the Ministry of Law and Human Rights of the Republic of Indonesia. However, the legal aid lawmakers are aware that the funds allocated in the APBN will not be able to fulfill all requests for legal aid

24 Siti Maimunawaroh, "Kewenangan Pemerintah Daerah dalam Pemenuhan Bantuan Hukum bagi Masyarakat Miskin di Kabupaten Jember", Lentera Hukum Vol. 5 No. 2, 2018, pp. 290-292. 
in all regions. For this reason, the Law on Legal Aid through the provisions of the Article allocates funds for the implementation of legal aid in the APBD. The Law on Legal Aid does not impose an obligation on regions to allocate funds for the implementation of legal aid. Because the rules described in Article 19 paragraph (1) use the phrase 'can', so there is a choice for the region whether to regulate it or not. However, if the region wishes to allocate funds for the implementation of legal aid in the APBD, the Regional Government and the Regional House of Representatives must regulate it in a Regional Regulation.

Local government is an important institution in the implementation of state life. In accordance with Indonesian laws and regulations, the Regional Government is the implementer of the principle of decentralization in which the central government delegates part of its affairs to the regions to be managed independently. In this context, local governments are given the freedom to regulate themselves in the context of implementing regional autonomy, among others through the issuance of regional legal products. Through its authority, basically the Regional Government has the opportunity to implement legal aid activities, especially for the poor.

As part of the Unitary State of the Republic of Indonesia, the Regional Government as regulated in Article 18 of the 1945 Constitution of the Republic of Indonesia and Law Number 23 of 2014 concerning Regional Government, basically also assumes responsibility for the obligations of the state in guaranteeing and protecting constitutional rights. citizen. So far, the provision of legal aid has not touched many people or groups of people who are economically disadvantaged, so that they find it difficult to access justice because they are hampered by their inability to realize their constitutional rights. ${ }^{25}$

In addition, the local government's alignment with the people who have problems with the law through efforts to provide legal assistance has not been an initiative of the local government. So far, the approach to strengthening the underprivileged is basically done through programs for alleviating and strengthening the community's economy. Even if there are programs related to the legal field, they are generally carried out in the form of legal counseling or socialization of statutory regulations.

Departing from this situation, the Regional Government should participate in assuming the responsibility of the state in guaranteeing and protecting the right of every citizen to gain access to justice through the implementation of a legal aid program as outlined in a Regional Regulation. The existence of a Regional Regulation concerning legal aid is an urgent matter to be realized as a form of commitment and political will of every Regional Government towards the underprivileged community in their area.

25 M. Cappelleti \& B. Garth, Acces to Justice, Italy: Giuffre-Sijthoff, 1978, pp. 22-25. 
The Regional Regulation on the Implementation of Legal Aid for the poor that will be established by the Regional Government is basically a regulation aimed at ensuring the existence of public services provided by the Regional Government to the community. Through this regional regulation, the regional government wants to reaffirm the types of public services provided, how to get access to them and the clarity of the regional government's obligations and the rights of its citizens. Through this Regional Regulation, the principles of guaranteeing and protecting the right to legal aid are regulated as part of public services for local residents. Therefore, the existence of a Regional Regulation concerning the Implementation of Legal Aid is urgent to be held not only in order to guarantee the right to legal assistance in order to improve public services, but also to guarantee the constitutional rights of citizens in order to achieve the goal of a prosperous regional people.

\section{CONCLUSION}

In the end, this study concluded and underlined that the right to obtain legal assistance is a fundamental or human right for someone who is in trouble with the law. Because obtaining legal assistance is one form of access to justice for those who are or are dealing with legal problems. The provision of legal aid is not only regulated in the Constitution but is also regulated in the regulations below it up to the Regional Regulation level. The Regional Government can allocate funds for the implementation of legal aid in the APBD, then the Regional Government and DPRD must regulate it in a Regional Regulation. There is still a lack of socialization carried out by both the Court and LBH regarding the provision of free legal aid to underprivileged communities, especially in regional areas. This has resulted in most of the community, especially the poor, who are not aware of the provision of free legal aid, then the limited funds provided by the Regional Government are one of the causes of the lack of socialization regarding the provision of free legal aid to the community.

\section{REFERENCES}

Abdurrahman, A. (1983). Aspek-Aspek Bantuan Hukum di Indonesia. Jakarta: Penerbit Cendana Press.

Amiruddin, A., \& Asikin, Z. (2006). Pengantar Metode Penelitian Hukum. Jakarta: PT. Raja Garafindo Persada. 
Tiara Putri Syahara

Anwar, Y., \& Adang, A. (2009). Sistem Peradilan Pidana (Konsep, Komponen, dan Pelaksanaannya dalam Penegakan Hukum di Indonesia). Bandung: Widya Padjajaran.

Asfinawati, A., \& Santosa, M. A. (2007). Bantuan Hukum Akses Masyarakat Marjinal Terhadap Keadilan Tinjauan Sejarah, Konsep, Kebijakan, Penerapan, dan Perbandingan di Berbagai Negara. Jakarta: LBH Jakarta.

Badan Pembinaan Hukum Nasional. (2016). Implementasi UndangUndang Nomor 16 Tahun 2011 tentang Bantuan Hukum. Jakarta: BPHN.

Bakker, L., \& Timmer, J. (2014). Justice in Indonesia: The social life of a momentous concept. The Asia Pacific Journal of Anthropology, 15(4), 293-301.

Bakri, D. S. A. B. (2020). Bantuan Hukum Pro Bono Publico dalam Pemenuhan Hak Memperoleh Keadilan dan Persamaan di Muka Hukum di Provinsi Jawa Timur. Jurnal Panorama Hukum, 5(2), 205-215.

Cappelleti, M., \& Garth, G. (1978). Access to Justice. Italy: GiuffreSijthoff,

Harahap, M. Y. (2009). Pembahasan Permasalahan dan Penerapan KUHAP Penyidikan dan Penuntutan. Jakarta: Sinar Grafika.

Kaligis, O. C. (2006). Perlindungan Hukum Atas Hak Asasi Tersangka, Terdakwa dan Terpidana. Bandung: PT Alumni.

Maimunawaroh, S., \& Antikowati, A. (2018). Kewenangan Pemerintah Daerah dalam Pemenuhan Bantuan Hukum bagi Masyarakat Miskin di Kabupaten Jember. Lentera Hukum, 5(2), 259-276.

Manan, B. (2001). Perkembangan Pemikiran dan Pengaturan Hak Asasi Manusia di Indonesia, Yayasan Hak Asasi Manusia, Demokrasi dan Supremasi Hukum. Bandung: Alumni.

Nasution, A. B. (2007). Bantuan Hukum di Indonesia. Jakarta: LP3ES

Reksodiputro, N. (1994). Hak Asasi Manusia Dalam Sistem Peradilan Pidana. Jakarta: Pusat Pelayanan Keadilan dan Pengabdian Hukum.

Republic of Indonesia. (1945). Undang-Undang Dasar Negara Republik Indonesia Tahun 1945.

Republic of Indonesia. (1981). Undang-Undang Nomor 8 Tahun 1981 tentang Kitab Undang-ndang Hukum Acara Pidana.

Republic of Indonesia. (1999). Undang-Undang Nomor 39 Tahun 1999 tentang Hak Asasi Manusia.

Republic of Indonesia. (2004). Undang-Undang Nomor 4 Tahun 2004 tentang Kekuasaan Kehakiman.

Republic of Indonesia. (2011). Undang-Undang Nomor 16 Tahun 2011 tentang Bantuan Hukum. 
Republic of Indonesia. (2013). Peraturan Pemerintah Nomor 42 Tahun 2013 tentang Syarat dan Tata Cara Pemberian Bantuan Hukum dan Penyaluran Dana Bantuan Hukum.

Republic of Indonesia. (2014). Undang-Undang Nomor 23 Tahun 2014 tentang Pemerintah Daerah.

Republic of Indonesia. (2015). Keputusan Menteri Hukum dan Hak Asasi Manusia No. M.HH-01.HN.03.03 Tahun 2015 tentang Besaran Biaya Bantuan Hukum Litigasi dan Nonlitigasi.

Rukmini, M. (2007). Perlindungan HAM Melalui Asas Praduga Tidak Bersalah dan Asas Persamaan Kedudukan Dalam Hukum Pada Sistem Peradilan Pidana Indonesia. Bandung: Alumni.

Santiadi, K. (2019). Expanding Access to Justice through E-Court in Indonesia. Prophetic Law Review, 1(1), 75-89.

Soekanto, S. (1983). Bantuan Hukum suatu Tinjauan Sosio Yuridis. Jakarta: Ghalia Indonesia.

Soekanto, S. (2008). Faktor-Faktor Yang Mempengaruhi Penegakan Hukum. Jakarta: PT Raja Grafindo Persada.

Sunggono, B., \& Harianto, A. (2001). Bantuan Hukum dan Hak Asasi Manusia. Bandung: Mandar Maju.

Suradji, S. (2008). Etika dan Penegakan Kode Etik Profesi Hukum (Advokat). Jakarta: Badan Pembinaan Hukum Nasional Departemen Hukum dan HAM RI.

Tuslian, W. N. (2020, March). Assessing Development of Access to Justice in Indonesia Through Capability Approach. In 3rd International Conference on Law and Governance (ICLAVE 2019) (pp. 226-230). Atlantis Press.

Van Voorst, R. (2014). The right to aid: perceptions and practices of justice in a flood-hazard context in Jakarta, Indonesia. The Asia Pacific Journal of Anthropology, 15(4), 339-356.

Winata, F. H. (2009). Probono Publico, Hak Konstitusional Fakir Miskin Untuk Memeperoleh Bantuan Hukum. Jakarta: PT. Gramedia Pustaka Utama.

YLBHI. (2014). Panduan Bantuan Hukum di Indonesia. Jakarta: Yayasan Obor Indonesia.

Zen, A. P. M., \& Hutagalung, D. (2006). Panduan Bantuan Hukum di Indonesia. Jakarta: YLBHI dan PSHK. 


\title{
Law and order exist for the purpose of establishing justice and when they fail in this purpose they become the dangerously structured dams that block the flow of social progress.
}

\author{
Martin Luther King, Jr
}

\section{Conflicting Interest Statement}

All authors declared that there is no potential conflict of interest on publishing this article.

\section{Funding}

None

\section{Publishing Ethical and Originality Statement}

All authors declared that this work is original and has never been published in any form and in any media, nor is it under consideration for publication in any journal, and all sources cited in this work refer to the basic standards of scientific citation.

Cite this article as:

Syahara, T. P. (2021). Implementation of Legal Aid by the Local Government (Case Study of the Local Government of Jember Regency). The Indonesian Journal of International Clinical Legal Education, 3(4), 499-516. https://doi.org/10.15294/ijicle.v3i4.48282 